\title{
The Effectiveness of Cloud Computing Based Program in Developing EFL Third Year Preparatory School Students' Grammar Achievement and Vocabulary Retention
}

Nermin Samir Mohammed El-Garhy An English teacher

\section{Abstract}

7 his study aimed at the development of cloud computing based program on grammar achievement and vocabulary retention among third year preparatory students using cloud computing based program. Thirty -five third year preparatory students at EL-Shaheed Abd Allah Mohamed Abd Allah Preparatory School, Zagazig, El Sharkia Governorate, served as a treatment group, and 35 third year preparatory students at Sharweda Preparatory School, Zagazig, El Sharkia Governorate, served as a control group. The treatment group was taught using cloud computing based program. The control group was taught using the traditional method. Grammar test and vocabulary retention were administered to the students in the two groups as pre-post tests. The proposed program was taught over a period of month (five periods per week). Delayed vocabulary retention was administered to the students in the two groups as a delayed test, two weeks after the end of the experiment. The results of the study showed that the treatment group students outperformed the non-treatment group students in grammar and vocabulary retention tests. The researcher suggested that the EFL program based on cloud computing was effective in developing the students' grammar and vocabulary retention.

Keywords: cloud computing-based program, grammar, vocabulary retention

\section{1-Introduction:}

Language is one of the most essential means of communication between communities. Anyone who wants to convey messages or feelings whether orally or in a written form should use language. It is known that English language is considered by many people to be one of the important languages all over the world because it is an international one. Thus, 
learning and teaching English as a second language (ESL) / as a foreign language (EFL) have become necessary in all countries that don't use English as a first language. In order to achieve the process of learning English, one must acquire its vocabulary, grammar, pronunciation and the four skills: listening, reading, speaking, and writing.

Learning English as a foreign language always is a big challenge for the learners. The most challenging part is when the learners find the language systematic. It means that EFL learners need to equip their knowledge of language with certain amount of rules in order to be proficient. Lack of grammar knowledge causes not to achieve proficiency level of a foreign language so that knowing certain amount of structure is mandatory; however. Language learners face grammar difficulty when the rules are presented by the teachers, and such difficulty is more challenging especially for EFL learners because the language is not spoken in their daily life.

Grammar is always within the language and should be seen as an inseparable part. As Batstone (1994) and Ramirez (1995) defined grammar as a vast and various phenomenon which vitalizes form, meaning and use, it should not be seen as only a set of despotic structures and fixed rules in the language. Grammar is a component of all productive and receptive skills. Therefore, it cannot be ignored, it is better to experience simplifying and facilitating ways of learning grammar. In this path, teachers can equip learners with certain amount of output and help them to put grammar into effective use by applying grammar consciousness-raising approach in English classrooms.

Vocabulary is one of the language aspects that has to be learned when people are learning a foreign language. By learning new vocabulary, learners can improve their listening, speaking, reading and writing skills. Folse (2008) mentioned that English language learners need a continuous knowledge of vocabulary in order to improve comprehension and production in the foreign language. He added that while a basic level of vocabulary will 
allow learners to communicate some ideas to a certain degree, better communication can be happened when learners have acquired more vocabulary.

After decades of neglect, second language vocabulary acquisition has begun to receive increasing attention in recent years. Remembering new words is not often an easy job for learners. That is why teachers try to utilize various techniques to present new words to them.

Souleyman(2009) mentioned that retention is a function of memory. For him that can include more complex functions as memorizing or learning, retention, recall, and recognition. He (Ibid) adds that there are processes which precede retention such as noticing, intake, and storage in the short term memory and later in the long-term memory.

There are two kinds of vocabulary retention: immediate retention and delayed retention. Souleyman (2009) defines immediate retention as the level of retention of the newly comprehended piece of information as measured by a test after the experimental immediately. It can also be referred to as medium term retention.

Delayed retention can be referred to as long-term retention of the items. Regarding the long-term vocabulary retention, Min \& Hsu (2008) state that almost all learners retain a significant amount of receptive vocabulary knowledge over one month; but approximately half of them show a significant decline in productive word knowledge.

During the last years, the nature of the Internet was constantly changing from a place used to read web pages to an environment that allows end-users to run software applications. Interactivity and collaboration have become the keywords of the new web content.

There is no doubt the future belongs to the Web 3.0 (also called the intelligent Web) (DeCoufle, 2009). This new environment supports the creation of à new generation of 
applications that are able to run on a wide range of hardware devices, like mobile phones or PDAs, while storing their data inside the cloud.

The need for education is increasing constantly and the development and the improvement of the e-learning solutions is necessary. Also, the e-learning systems need to keep the pace with the technology, so the new direction is to use cloud computing. There are several cloud computing services providers that offer support for educational systems. Among them are Amazon, Google, Yahoo, Microsoft etc.

The cloud computing term was derived from the way the Internet is often represented in network diagrams. Due to the fact it involves the existence of data centers that are able to provide services; the cloud can be seen as a Si the unique access point for all the requests coming from the world wide spread clients. Cloud computing comprises of three layers (Creeger and Roundtable, 2009):

- Infrastructure as a service (JaaS)

- Platform as a service (PaaS)

- Software as a service (SaaS)

Cloud computing is by no means different from grid computing. The aim of a grid computing architecture is to solve large tasks by using the advantage of concurrency and parallelism, while the cloud is focused on collaboration.

Cloud computing becomes very popular because it moves the processing efforts from the local devices to the data center facilities. Therefore, any device, like an Internet connected phone, could be able to solve complex equations by simply passing the specific arguments to a service running at the data center level that will be capable to give back the results in a very short time. In these conditions, the security of data and applications becomes a very major issue.

Cloud computing is widely accepted today due to its key advantages: 
- The cost is low or even free in some cases. Also, ' there are no costs (or very small ones) for hardware upgrades;

- for some applications (like spreadsheets) it can be used even in the offline mode, so when the client goes back online a synchronization process is refreshing the data;

- the strong connection that exists today between the users and their personal computers can be completely broken because a customer can reach the same result by using any Internet connected device having minimum software requirements;

- devices with minimal hardware requirements (mobile phones, for example) could be successfully used as cloud clients;

- in order to become part of the cloud, there is no need to download or install a specific software, only the Internet connection is required;

- the cost of licensing different software packages is moved to the data center level, so there is no need to upgrade the local system when new service packs or patches are released;

- crash recovery is nearly unneeded. If the client computer crashes, there are almost no data lost because everything is stored into the cloud.

- $\quad$ Some of the main cloud computing disadvantages are the following:

- the Internet connection speed may affect the overall performances;

- on a long term basis, the data center subscription fee may be more expensive than buying the hardware;

- The service quality is crucial and the need of the backups is critical when speaking about data security.

\section{2- Context of the Problem:}

In spite of the importance of the EFL grammar and vocabulary retention there is a lack in the EFL grammar and vocabulary retention among third year preparatory students. 
Out of the researcher's experience as an EFL demonstrator, it has been noticed that third year preparatory students encounter difficulties in grammar and vocabulary retention. This inefficiency in EFL grammar and vocabulary retention of third year preparatory students may be due to lack of practice to sum up, third year preparatory students lack EFL grammar and vocabulary retention, so the researcher proposes the cloud computing based program for developing their grammar and vocabulary retention.

\section{3- Statement of problem:}

In spite of the importance of EFL grammar and vocabulary retention, third year preparatory students lack these skills, thus, there is a need for an effective program for developing some EFL grammar and vocabulary retention among third year preparatory students. So, the following study aimed at the development of a cloud computing based program in developing some EFL grammar and vocabulary retention.

\section{4- Questions of Study:}

To face this problem, the present study answered the following questions:

1. What're the grammar of the third year preparatory English curriculum and vocabulary components that need to be mastered by the students?

2. How can a program be designed on the basis of cloud computing to provide students with the opportunities to master the required grammar and vocabulary retention?

3. How far is this program effective on enhancing grammar and vocabulary retention?

\section{5- Purpose of the study:}

This study aimed at investigating the effect of using cloud computing based program on grammar and vocabulary retention of third year preparatory students.

\section{6- Sample of the study:}

The Participants were 35 third year preparatory students 
at EL-Shaheed Abd Allah Mohamed Abd Allah Preparatory School, Zagazig, El Sharkia Governorate, served as an experimental group, and 30 third year preparatory students at Sharweda Preparatory School, Zagazig, El Sharkia Governorate, served as a control group. The experimental group was taught using cloud computing based program. The control group was taught using the traditional method.

\section{7- Hypotheses of the study:}

Based on the theoretical background, the review of the previous studies and the general discussion, the study hypotheses could be formulated in as following:

1. There is a statistically significant difference between the mean scores of the treatment group and the nontreatment one in the post grammar test in favor of the treatment group .

2. There is a statistically significant difference between the mean scores of the treatment group and the nontreatment one in the post vocabulary retention test in favor of the treatment group .

3. There is a statistically significant difference between the mean scores of the treatment group in the pre and post grammar test in favor of the post test.

4. There is a statistically significant difference between the mean scores of the treatment group in the pre and post vocabulary retention test in favor of the post test.

5. There is an effect of the cloud computing based program on the treatment group in the grammar test.

6. There is an effect of the cloud computing based program on the experimental group in the vocabulary retention test.

7. There is a statistically significant difference between the mean scores of the treatment group and the nontreatment one in the delayed vocabulary retention test in favor of the treatment group. 


\section{8- Procedures of the study:}

In order to achieve the aims of the study, the following procedures will be adopted:

1. Reviewing the relevant literature and previous studies related to grammar and vocabulary retention to develop the grammar test and vocabulary retention test.

2. Reviewing the relevant literature and previous studies related to cloud computing based strategy to design the experiment.

3. Designing the instruments:

a. Preparing grammar achievement test.

b. Preparing vocabulary retention test.

4. Designing the cloud computing based program.

5. Submitting the grammar achievement and vocabulary retention test to a jury of EFL specialists to verify its contents and modify it to reach its final forms.

6. Selecting sample of third year preparatory school EFL students and dividing them into two groups (the treatment group and non-treatment group).

7. Pre administering the grammar and vocabulary retention tests to both groups.

8. Teaching the experimental treatment material to the treatment group.

9. Post administering the grammar and vocabulary retention tests to both groups.

10. Administering the delayed vocabulary retention test again to the both groups of the study after two weeks from the post-administration.

11. Comparing the results of both.

12. Collecting and analyzing data.

13. Providing the study conclusions, recommendations and suggestions for further research.

\section{9-Significance of the study:}

This study may be useful for the following categories: 
1. Students: by improving grammar and vocabulary retention among students of third year preparatory through the suggested program.

2. Teachers: by designing a program for English language teachers that may help them to teach grammar and vocabulary.

3. Curriculum developers: by drawing the attention of curriculum designers and developers to the importance of including grammar and vocabulary in the textbooks for students.

\section{0- Instruments and materials:}

1. A grammar test.

2. A vocabulary retention test.

3. A delayed vocabulary retention test.

4. A cloud computing based program.

\section{1-1-Designing the grammar pre-post test}

\section{Aim of the test:}

The aim of this test was to measure EFL third year preparatory students' grammar achievement after administering the proposed program in an attempt to measure the effect of the proposed program on developing grammar. It was used as a prepost test.

\section{Description of the test:}

The test consists of 40 items that measured the grammar identified as suitable for third year preparatory students and write (a letter, a paragraph and an-email).

\section{1-2-Designing the vocabulary retention pre-post test:}

\section{Aim of the test:}

The aim of this test was to measure EFL third year preparatory students' vocabulary retention after administering the proposed program in an attempt to measure the effect of the 
proposed program on developing vocabulary retention. It was used as a pre- post test.

\section{Description of the test :}

The test consists of 40 items that measured the vocabulary retention identified as suitable for third year preparatory students.

\section{Determining the Validity of the Research Instruments:}

The EFL grammar achievement and vocabulary retention were submitted to jury members, they were asked to determine the validity of the instruments in terms of clarity of instructions, items and its suitability for the students' level. They indicated that the tests instructions were clear and suitable for students' levels and background knowledge. Therefore, they were considered valid measures of grammar achievement and vocabulary retention (Face Validity). To ensure the content validity of the tests, they were developed in the light of a systematic and accurate review of literature and previous studies. This accurate and systematic review determined the general form of the tests, questions and methods of correction. Therefore, the content of the tests was representative that was intended to be measured. Thus, they were valid and having content validity.

\section{Determining the Reliability of the Research Instruments:}

The reliability of the instruments was measured by using the test - retest method. The instruments were administered to a group of third year students at EL-Nassria Preparatory School, Zagazig, El Sharkia Governorate, Egypt. Then, they were administered to the same group again after two weeks. The Pearson correlation between the two administrations was (0.87) at the 0.1 level. Therefore, the instruments were reliable.

\section{A program based on Cloud Computing:}

For achieving the purpose of the research, the researcher designed a program based on cloud computing. After assessing 
third year at EL-Shaheed Abd Allah Mohamed Abd Allah Preparatory School, Zagazig, El Sharkia Governorate, Egypt grammar achievement and vocabulary retention, the study sample attended the program based on cloud computing.

\section{Objective of Cloud Computing based Program:}

The program aimed at developing EFL grammar achievement and vocabulary retention among third year students at EL-Shaheed Abd Allah Mohamed Abd Allah Preparatory School, Zagazig, El Sharkia Governorate, Egypt.

\section{Content of Cloud Computing based Program:}

The topics chosen for the program were selected from books and studies enriched with topics that motivate students. They contained variety of topics designed for developing grammar achievement and vocabulary retention. They were suitable for the third year students' at EL-Shaheed Abd Allah Mohamed Abd Allah Preparatory School, Zagazig, El Sharkia Governorate, Egypt.

\section{Framework of Cloud Computing based Program:}

The treatment began in October 2016 and continued $15^{\text {th }}$ December 2016. The teacher met for four hours per week for twelve weeks and also communicated with them via Google Drive. Week (1) was used for pre-testing and week (12) was used for post-testing. Each session was devoted to the following: introduction, objectives, procedures, the role of the teacher and student and finally the performance.

The program was taught to students by a teacher. It lasted twelve weeks with twenty instructional sessions and each session lasted for 90 minutes. At the beginning of the program, the teacher introduced to the students what they are going to do. First, she told them about the objectives of the program and what they are supposed to gain as a result of their participation in the program. After that she told them about the importance of grammar achievement and vocabulary retention. Then, she began to introduce the concept of cloud computing based program and its importance for language learning and EFL grammar achievement and vocabulary retention. 
Following the introduction of the program, the rest of the program were instructional sessions through which EFL grammar achievement and vocabulary retention were introduced. At the beginning of each session the teacher presented the objectives of the session, the teacher's role, the student's role, the instructional materials that will be used, the activities they will perform and ways of evaluating their progress. At the end of the each session, the teacher gave students some activities related to what they had learned in order to be sure that they mastered grammar achievement and vocabulary retention in each session. At the end of the program, the teacher assessed the students' achievement after implementing the program using the EFL grammar achievement and vocabulary retention tests.

\section{2- Findings of the Study:}

This study aimed at examining the development of cloud computing-based program on grammar and vocabulary retention of third year preparatory stage students SPSS was used for analyzing the data of the post administration of the tool. One way ANOVA was used for comparing the means of the experimental group the control group in grammar and vocabulary retention.

Before presenting results of the study and analyzing them according to the hypotheses of the study, a comparison between the control and experiential groups on the pre-test was conducted using t-test for independent samples to examine if there were any statically significant differences between the two group before implementing the program.

In order to make sure that the improvement of students was attributed to the effect of teaching by using the cloud computing based program, some variables have been controlled in order to make sure that both the experimental and the control groups were equivalent. These variables included: the learners ages which ranged from 14 to 15years old, both belong to a similar social background (Egyptian rural background). 
Table (1) T-test Results of the Pre Administration of the grammar Test Comparing the Experimental Group to the Control Group

\begin{tabular}{|c|c|c|c|c|c|c|c|}
\hline Group & $\mathrm{N}$ & Mean & $\begin{array}{c}\text { Std. } \\
\text { Deviation }\end{array}$ & $\begin{array}{c}\text { Std.Error } \\
\text { Mean }\end{array}$ & t & df & $\begin{array}{c}\text { Sig.(2- } \\
\text { tailed) }\end{array}$ \\
\hline Experimenal & $\mathbf{3 5}$ & $\mathbf{2 2 . 8 8 5 7}$ & $\mathbf{7 . 7 6 0 2 7}$ & $\mathbf{1 . 3 1 1 7 3}$ & $\mathbf{0 . 7 7 2}$ & $\mathbf{3 4}$ & $\mathbf{0 . 4 4 6}$ \\
\hline Control & $\mathbf{3 5}$ & $\mathbf{2 2 . 6 0 0 0}$ & $\mathbf{7 . 7 8 0 8 2}$ & $\mathbf{1 . 3 1 5 2 0}$ & & & \\
\hline
\end{tabular}

The above table shows that there is no significant difference $[t(34)=0.772, p=0.446]$ between the mean scores of the experimental group [M=22.8857, $\mathrm{SD}=7.76027]$ and the mean scores of the control group $[\mathrm{M}=22.6000, \mathrm{SD}=7.78082]$. This indicates homogeneity of the two groups. That is to say, the two groups are at almost the same level of performance in the grammar. Thus, any variance between the two groups that may happen after the experiment could be attributed to the effect of the experiment. The pre-test scores revealed that most of the students have average proficiency in grammar test.

Table (2) T-test Results of the Pre Administration of the Vocabulary Retention Test Comparing the Experimental Group and the Control Group

\begin{tabular}{|c|c|c|c|c|c|c|c|}
\hline Group & N & Mean & $\begin{array}{c}\text { Std. } \\
\text { Deviation }\end{array}$ & $\begin{array}{c}\text { Std.Error } \\
\text { Mean }\end{array}$ & t & df & $\begin{array}{c}\text { Sig. (2- } \\
\text { tailed) }\end{array}$ \\
\hline Experimental & 35 & $\mathbf{1 4 . 2 7 1 4}$ & $\mathbf{4 . 5 8 4 7 3}$ & $\mathbf{0 . 7 7 4 9 6}$ & \multirow{2}{*}{0.480} & 34 & $\mathbf{0 . 6 3 5}$ \\
\hline Control & 35 & $\mathbf{1 3 . 4 8 5 7}$ & $\mathbf{8 . 9 0 1 8 2}$ & $\mathbf{1 . 5 0 4 6 8}$ & & & \\
\hline
\end{tabular}

The above table shows that there is no significant difference $[t(34)=0.480, p=0.635]$ between the mean scores of the experimental group $[\mathrm{M}=14.2714, \mathrm{SD}=4.58473]$ and the mean scores of the control group [M=13.4857, SD = 8.90182]. This shows homogeneity of the two groups. That is to say, the two groups are at almost the same level of performance in the vocabulary retention. Thus, any variance between the two groups that may happen after the experiment could be attributed to the effect of the experiment. The pre-test scores revealed that most of the students have average proficiency in the vocabulary retention test.

\section{Hypothesis 1:}

It has been hypothesized that " There is a statistically significant difference between the mean scores of the experimental group and the control one in the post grammar test in favor of the experimental group". 
A paired samples t-test was used (see table 3).

Table (3) T- Test Results of the Post Administration of grammar Test Comparing the Experimental Group and the Control Group

\begin{tabular}{|c|c|c|c|c|c|c|c|}
\hline The Group & $\mathrm{N}$ & $\begin{array}{c}\text { Std.error } \\
\text { Mean }\end{array}$ & Mean & $\begin{array}{c}\text { Std. } \\
\text { Deviation }\end{array}$ & $\begin{array}{c}\text { Compared } \\
\text { mean }\end{array}$ & $\begin{array}{c}\mathrm{T} \\
\text { value }\end{array}$ & $\begin{array}{c}\text { Sig. (2- } \\
\text { tailed) }\end{array}$ \\
\hline $\begin{array}{c}\text { The } \\
\text { experimental } \\
\text { group }\end{array}$ & 35 & 1.77189 & 27.0556 & 10.63134 & & & \\
\hline $\begin{array}{c}\text { The control } \\
\text { group }\end{array}$ & 35 & 1.30697 & 22.1389 & 7.84184 & 0.034 \\
\cline { 1 - 6 }
\end{tabular}

The above table indicates that there is a statistically significant difference at 0.05 level between the attained mean score of the control group and that of the experimental group in favor of the experimental group in the post administration of the grammar Test. The estimated t-value is 2.204 . It is significant at 0.05 level in favor of the post administration of the experimental group. The mean of the experimental group in the post administration is (27.0556) and that of the control group is (22.1389). So the mean of the experimental group is higher than that of the control one.

Moreover, the deviation of the experimental group is higher than that of the control group. The deviation of the experimental group is (10.63134) and that of the control group is (7.84184).

\section{Hypothesis 2:}

It has been hypothesized that" There is a statistically significant difference between the mean scores of the experimental group and the control one in the post vocabulary retention test in favor of the experimental group ".

A paired samples t-test was used to verify this hypothesis as shown in (table 4).

Table (4) T- Test Results of the Post Administration of Vocabulary Retention Test Comparing the Experimental Group and the Control Group

\begin{tabular}{|c|c|c|c|c|c|c|c|}
\hline The Group & $\mathrm{N}$ & $\begin{array}{c}\text { Std.error } \\
\text { mean }\end{array}$ & Mean & $\begin{array}{c}\text { Std. } \\
\text { deviation }\end{array}$ & $\begin{array}{c}\text { Compared } \\
\text { mean }\end{array}$ & $\begin{array}{c}\mathrm{T} \\
\text { value }\end{array}$ & $\begin{array}{c}\text { Sig. (2- } \\
\text { tailed) }\end{array}$ \\
\hline $\begin{array}{c}\text { The } \\
\text { experimental } \\
\text { group }\end{array}$ & 35 & 1.43717 & 23.0278 & 8.62301 & & & \\
\cline { 1 - 5 } $\begin{array}{c}\text { The control } \\
\text { group }\end{array}$ & 35 & 1.12764 & 16.5417 & 6.76585 & 6.48611 & 3.584 & 0.001 \\
\hline
\end{tabular}


The above table indicates that there is a statistically significant difference at 0.05 level between the attained mean scores of the control and experimental groups in favor of the experimental group's post administration of the vocabulary retention test. The estimated t-value is 3.584. It is significant at 0.05 level in favor of the post administration of the experimental group. The mean of the experimental group in the post administration is (23.0278) and that of the control group is (16.5417). So the mean of the experimental group is higher than that of the control one.

Moreover, the deviation of the experimental group is higher than that of the control group. The deviation of the experimental group is (8.62301) and that of the control group is (6.76585).

\section{Hypothesis 3:}

It has been hypothesized that" There is a statistically significant difference between the mean scores of the experimental group in the pre and post grammar test in favor of the post test ".

A paired samples t-test was used to verify this hypothesis as shown in (table 5).

Table (5) T- Test Results Comparing the Pre and Post Administration of the Experimental Group in the grammar Test

\begin{tabular}{|c|c|c|c|c|c|c|c|}
\hline The Group & $\mathrm{N}$ & $\begin{array}{c}\text { Std.error } \\
\text { mean }\end{array}$ & Mean & $\begin{array}{c}\text { Std. } \\
\text { deviation }\end{array}$ & $\begin{array}{c}\text { Compared } \\
\text { mean }\end{array}$ & $\begin{array}{c}\text { T } \\
\text { value }\end{array}$ & $\begin{array}{c}\text { Sig. (2- } \\
\text { tailed) }\end{array}$ \\
\hline $\begin{array}{c}\text { The } \\
\text { experimental } \\
\text { group Pre- } \\
\text { test }\end{array}$ & 35 & 1.26324 & 18.0286 & 7.47343 & 9.80000 & 4.435 & 0.000 \\
\hline $\begin{array}{c}\text { The } \\
\text { experimental } \\
\text { group Post- } \\
\text { test }\end{array}$ & 35 & 1.64060 & 27.8286 & 9.70593 & & & \\
\hline
\end{tabular}

From the previous table, it can be inferred that the obtained t value (4.435) is significant at 0.05 level. The mean scores of pre test (18.0286) is lower than that of the post test (27.8286), whereas the deviation of the scores of the pre test is lower than that of the post test. This means that there is an improvement in the performance of the experimental group due to the implementation of the program. 


\section{Hypothesis 4:}

It has been hypothesized that" There is a statistically significant difference between the mean scores of the experimental group in the pre and post vocabulary retention test in favor of the post test ".

A paired samples t-test was used to verify this hypothesis as shown in (table 5).

Table (5) T- Test Results Comparing the Pre and Post Administration of the Experimental Group in the vocabulary retention Test

\begin{tabular}{|c|c|c|c|c|c|c|c|}
\hline The Group & $\mathrm{N}$ & $\begin{array}{c}\text { Std.error } \\
\text { mean }\end{array}$ & Mean & $\begin{array}{c}\text { Std. } \\
\text { deviation }\end{array}$ & $\begin{array}{c}\text { Compared } \\
\text { mean }\end{array}$ & $\begin{array}{c}\text { T } \\
\text { value }\end{array}$ & $\begin{array}{c}\text { Sig. (2- } \\
\text { tailed) }\end{array}$ \\
\hline $\begin{array}{c}\text { The } \\
\text { experimental } \\
\text { group } \\
\text { Pre-test }\end{array}$ & 35 & 1.31477 & 13.4857 & 8.90182 & & & \\
\hline $\begin{array}{c}\text { The } \\
\text { experimental } \\
\text { group } \\
\text { Post-test }\end{array}$ & 35 & 1.50468 & 23.6857 & 7.77826 & & & \\
\hline
\end{tabular}

From the previous table, it can be inferred that the obtained $t$ value (5.492) is significant at 0.05 level. The mean score of the pre-test (13.4857) is lower than that of the post-test (23.6857), whereas the deviation of the scores of the pre test is higher than that of the post test. This means that there is an improvement in the performance of the experimental group due to the implementation of the program.

\section{Hypothesis 5:}

It has been hypothesized that" There is an effect of the cloud computing based program on the experimental group in the grammar test ". Cohen's equation was used to verify this hypothesis as shown in (table ' 7 ).

Table (6)Results of Cohen's Equation Comparing the Pre and Post Administrations of the Experimental Group in the Grammar Test

\begin{tabular}{|c|c|c|c|c|c|c|c|}
\hline The Group & $\mathrm{N}$ & $\begin{array}{c}\text { Compared } \\
\text { mean }\end{array}$ & $\begin{array}{c}\mathrm{T} \\
\text { value }\end{array}$ & $\mathrm{df}$ & \multicolumn{2}{|c|}{$\begin{array}{c}\text { 95\% Confidence } \\
\text { Interval of the } \\
\text { Difference }\end{array}$} & $\begin{array}{c}\text { Cohen's } \\
\text { value }\end{array}$ \\
\hline $\begin{array}{c}\text { The } \\
\text { experimental } \\
\text { group Pre -test }\end{array}$ & 35 & 9.80000 & 4.435 & 34 & Lower & Upper & 1.0756 \\
\cline { 1 - 2 } $\begin{array}{c}\text { The } \\
\text { experimental } \\
\text { group Post-test }\end{array}$ & 35 & & & & 5.30970 & 14.29030 & \\
\cline { 1 - 5 }
\end{tabular}


The effectiveness is measured through Cohen's equation as follows:

$$
\begin{aligned}
& \eta^{2}=\frac{T 2}{T 2+d f} \\
& E s=\frac{2 \sqrt{\eta 2}}{1-\eta^{-} 2} \\
& E s=1.0756
\end{aligned}
$$

As indicated in the previous table, it is obvious that the final value of Cohen's equation for the experimental group, comparing its pre and the post administrations in the grammar test is (1.0756). Based on that, it has been concluded that there is an effect of the cloud computing based program on the grammar.

In the aforementioned table, Cohen's equation value is significant at $95 \%$ confidence interval of the difference between the pre and the post administrations of the experimental group in the grammar test.

\section{Hypothesis 6:}

It has been hypothesized that" There is an effect of the cloud computing based program on the experimental group in the vocabulary retention test ". Cohen's equation was used to verify this hypothesis as shown in (table 7).

Table (7)Results of Cohen's Equation Comparing the Pre and Post Administrations of the Experimental Group in the Vocabulary Retention Test

\begin{tabular}{|c|c|c|c|c|c|c|c|}
\hline The Group & $\mathrm{N}$ & $\begin{array}{c}\text { Compared } \\
\text { mean }\end{array}$ & $\begin{array}{c}\mathrm{T} \\
\text { value }\end{array}$ & $\mathrm{df}$ & \multicolumn{2}{|c|}{$\begin{array}{c}\text { 95\%Confidence } \\
\text { Interval of the } \\
\text { Difference }\end{array}$} & $\begin{array}{c}\text { Cohen's } \\
\text { value }\end{array}$ \\
\cline { 1 - 3 } $\begin{array}{c}\text { The } \\
\text { experimental } \\
\text { group Pre-test }\end{array}$ & 35 & & & & Lower & Upper & \\
\cline { 1 - 2 } $\begin{array}{c}\text { The } \\
\text { experimental } \\
\text { group Post-test }\end{array}$ & 35 & 10.20000 & 5.492 & 34 & 1.3320 \\
\cline { 1 - 2 }
\end{tabular}

Cohen's equation was used to verify the effect of the program. We measure the effectiveness through the Cohen's equation: 


$$
\begin{aligned}
& \eta_{2}=\frac{T 2}{T 2+d f} \\
& E s=\frac{2 \sqrt{{ }^{n} 2}}{1-{ }^{n} 2}
\end{aligned}
$$

Es $=1.3320$

As indicated in the previous table, it is obvious that the final value of Cohen's equation for the experimental group, comparing its pre and the post administrations in the vocabulary retention test is (1.3320). Based on that, it has been concluded that there is an effect of the cloud computing based program on the vocabulary retention.

In the aforementioned table, Cohen's equation value is significant at 95\% confidence interval of the difference between the pre and the post administrations of the experimental group in the vocabulary retention test.

\section{Hypothesis 7:}

It has been hypothesized that" There is a statistically significant difference between the mean scores of the experimental group and the control one in the Delayed Vocabulary Retention Test in favor of the experimental group".

A paired samples t-test was used to verify this hypothesis as shown in (table 8).

Table (8) T- Test Results Comparing the Experimental Group and the Control Group in the Delayed Vocabulary Retention Test

\begin{tabular}{|c|c|c|c|c|c|c|c|}
\hline The Group & $\mathrm{N}$ & $\begin{array}{c}\text { Std. } \\
\text { error } \\
\text { mean }\end{array}$ & Mean & $\begin{array}{c}\text { Std. } \\
\text { deviation }\end{array}$ & $\begin{array}{c}\text { Compared } \\
\text { mean }\end{array}$ & $\begin{array}{c}\mathrm{T} \\
\text { value }\end{array}$ & $\begin{array}{c}\text { Sig.(2- } \\
\text { tailed) }\end{array}$ \\
\cline { 1 - 5 } $\begin{array}{c}\text { The control } \\
\text { group }\end{array}$ & 35 & $\mathbf{0 . 3 7 6 5 0}$ & 14.2571 & 2.22741 & 16.82857 & 11.305 & 0.000 \\
\hline $\begin{array}{c}\text { The } \\
\text { experimental } \\
\text { group }\end{array}$ & 35 & 1.53084 & 31.0857 & 9.05659 & & & \\
\hline
\end{tabular}

From the previous table, it can be inferred that the obtained t value (11.305) is significant at 0.05 level. The mean score of the control group (14.2571) is lower than that of the experimental group (31.0857), whereas the deviation of the scores of the experimental group is higher than that of the control group. This 
means that there is an improvement in the performance of the experimental group due to the implementation of the program.

\section{Discussion of the Results:}

The improvement in the performance of experimental group could be attributed to the students' awareness as they are somehow a part of a scientific experiment.

The results of the present study showed that the experimental group (taught through the cloud computing based program) performed better than the control one in the post administration of the grammar and vocabulary retention tests, since there were statistically significant differences at 0.05 between the mean scores of the experimental group and the control group in favor of the experimental group.

The students' progress in the post administration of the grammar test could be attributed to the fact that while using the cloud computing based program, students were interested in grammar and vocabulary about related topics to their syllabi. Students practiced cloud computing based program.

A well-conducted statistical analysis of the obtained results helped the researcher better understand and interpret the apparent improvement in the experimental group's performance. This is provided below:

The results of the present study showed that the experimental group (taught through the cloud computing based program) outperformed in the post administration of the grammar and vocabulary retention tests. The statistical results showed that there was a statistically significant difference between the mean score of the experimental group in their performance of each post test compared to the pre administration, favoring the post administration (Tables 3-8). The mean score of the experimental group in each test is higher than that of the control one, whereas the deviation of the experimental group is less than that of the control group. Hence, the significant difference, shown on the post administration of each test, is due to exposing this group to the cloud computing 
based program. Providing students with a variety of activities through this suggested program, changing the method of teaching, dividing the roles among students to improve their grammar and vocabulary retention, gave them the opportunity to interact with each other and to react to the material presented to them.

Through this interaction, they created cooperative environment in which less emphasis was placed on transmitting information from the teacher and more on the student. So the cloud computing based program adopted throughout the study and the teaching program which is based on this approach helped the students go through several steps.

During the experimentation, the researcher noticed that the preparatory students (the participants) have a positive attitude towards the grammar. For many students, the grammar activities changed the way they feel about grammar. Giving students grammar topics related to their lessons increased their motivation and involvement and improved their writing performance.Students write with greater fluency and satisfaction because they are writing about topics that engage and interest them. Moreover, this gives students more commitment to the task and they feel a greater sense of ownership.

\subsection{Conclusions:}

The present study aimed at investigating the efficacy of the EFL cloud computing based programme in developing the participants' grammar and vocabulary retention. Most of the previous studies provided ample evidence supporting the value of the program based on cloud computing. Hence, the program based on cloud computing was suggested to develop students' grammar and vocabulary retention.

The program consisted of 20 lessons + a revision unit. The program activities were hoped to enhance the students' grammar and vocabulary retention.

The pre-posttest experimental group/control group design has been adopted. Two classes were randomly selected from 
both EL-Shaheed Abdullah Mohammed Abdullah preparatory school and Shreweda Preparatory School.

At the end of the experimentation, the students' performance was determined by administering the grammar and vocabulary retention tests. The conclusions are provided in the following sequence:

a. The program based on cloud computing has been effective in developing preparatory students' grammar.

b. The program based on cloud computing has been effective in developing preparatory students' vocabulary retention. There are three dimensions to vocabulary retention: noticing, retrieval, and creative (generative) use. The students become very careful about new vocabulary. They give attention to the vocabulary and are aware of it. They are being able to recall the vocabulary from the memory during the task. They using the vocabulary in new context with different meaning.

c. The program based on cloud computing proved to be effective in overcoming the students' problem about dealing with their teacher and classmates through the participation in workshops and cooperative activities.

d. Writing activities helped the students recognize their errors, and improve their writing performance through practicing different exercises regarding .

e. Giving students writing topics related to their lessons increased their involvement and improving their writing performance.

\section{Recommendations:}

In the light of the present study results, the following points would be recommended:

1. Teachers are recommended to encourage students involving in the writing activities to overcome their problems in writing.

2. Cloud computing should be used in teaching students to enhance their collaborative skills and self-efficacy beliefs. 
3. EFL teachers should check and monitor the level of students' grammar and vocabulary retention individually from time to time in order to diagnose points of weakness and thus identify the methods of suitable remedy so that readers can make sense of what they read.

4. EFL teachers should be aware of the tools and rating scales necessary for measuring and monitoring the students' grammar and vocabulary retention so as to be able to make progress writing file each student.

5. The present program can be adopted for teaching grammar and vocabulary retention to students' at the primary stage and other stages taking into considerations students' age, needs, interests and linguistic proficiency levels.

\subsection{Suggestions for Further Research:}

In the light of the study findings and results, some points are suggested for further research:

a. The effect of the program based on cloud computing on other educational stages (elementary, secondary, university).

b. The effect of the program based on cloud computing on other language skills such as reading and speaking.

c. The effect of vocabulary retention on language skills such as reading, listening and speaking.

d. Further research will be needed to investigate the effect of age, gender and computer experience upon vocabulary.

e. Investigating the effects of cloud computing based program on the students' attitudes towards English as a foreign language.

f. Using E-Learning to improve grammar and vocabulary retention.

\section{References:}

Batstone, R. (1994). Grammar. Oxford: Oxford University Press. Creeger M., CTO Roundtable: Cloud Computing Communications of the ACM, vol. 52, no. 8, august 2009, pp. 50-56. 
DeCoufle B., The impact of cloud computing in schools, The Datacenter Journal, http://datacenterjournal.com/content/view/3032/40, November2016.

Folse, K.S. (2008). Six vocabulary Activities for the English language classroom. English Teaching From, 46(3), p.12.

Min, H.T. \& Hsu, W.S. (2008). The Impact of Supplemental Reading on vocabulary Acquisition and Retention with EFL learners in Taiwan. Humanities \& social sciences, 53(1), 83115.

Ramirez, A. G. (1995). Creative contexts for second language acquisition. White Plains, NY: Longman Publishers.

Sauleyman, H, M. (2009). Implicit and Explicit vocabulary Acquisition with a computer-Assissted Hypertext Reading task. Comprehension and Retention. (Unpublished Ph.D. dissertation), university of Arizona, USA. 
